\title{
特別養護老人ホームの火災時における入所者の避難行動能力と 職員の介助能力についての研究 \\ A STUDY ON STANDARDIZATION OF A COMPOSITE EVALUATION SCALE FOR AN ELDERLY'S ESCAPE ABILITY IN A FIRE EMERGENCY AT NURSING HOME
}

\author{
佐藤克之* \\ Katuyuki SATOH
}

\begin{abstract}
The objective of this inveatigation/study is to establish some kind of system to evaluate to what extent staff and others at welfare institutions can manage to safely take out the aged people who are unable to asecape by themselves when a fire breaks out.

We have conducted the following survey, based on our preliminary plan, at special nuesing homes for the aged people.

1) We observed the escaping ability of all patients/residents in case of a fire through fire escape drills at one institution. According to tha result, it was found that 84 percent of patients/residents were not capable of self-escape, and that rescue at night was more difficult.

2) Conducting fire escape drills, we confirmed the following. It was possible to take out all of them safely during the daytime when enough staffs were available. On the other hand, in the evening only a partial rescue was possible, which necessitated the help of people in the neighborhood. Also, at least two escape hatches on a floor were needed.

3) Inspecting both visible and invisible dangerous factors in the buildings, we found that hoses form indoor fireplugs impeded smooth evacuation, that two-directions for fire escape-were not adequately provided, and other problems. We discussed countermeasures for these problems.
\end{abstract}

Keywords: Composite evaluation scale, Elderly's escape ability, Nursing home

\section{I.はじめに}

わが国の高齢化に伴う社会変動は, 急速に進展してお り，とくに寝たきり老人や痴呆性老人などの要介護老人 の増加は, 毉急の社会問題になってきていることは改め ていうまでもない。他者の介護を必要とする高跘者は, 当然のことでもあるが災害弱者でもあり, 東京都東村山 市の特別養護老人ホーム「松寿園」での火災による惨事 は，如実にそのことを物語っている。この悲惨な災害が 契機となり, 特別養護老人ホームなどの社会福祉施設に おけるスプリンクラーの設置義務が課せられるなど, 制 度的な改正までに発展じてきたが, このようなハード面 だけの防火対策では不十分であることは，高齢化社会に おける住環境の研究 (小野田・佐藤, 1986)文)でも報告泣) されているし一般的にも関係者のよく知るところであ る。

言うまでもなく，日頃から火災発生に対する予防対策
を充実しておくことが不可欠な課題であるが, 万一の火 災発生に対して日常的な配慮による対応策 (消火・通 報・避難等) に万全を期することが最も重要である。

\section{II. 研究目的}

私どもは，「松寿園の火災」以前から，火災発生時に おける日常的な配虑による対応策を検討してきた。特 に，北海道では毎年 120 130人の火災による焼死者を 出している。この焼死者の数は東京都での焼死者数亡毎 年ほぼ同数であり, 人口 10 万人当たりでの焼死者の割 合は 1.1 人，これに対して北海道では， 2.3 人と約 2 倍 の焼死者を出しており, 中でも 65 藏以上の高踰者の割 合では 10 万人に対して東京で 3.1 人，北海道で 4.8 人 と約 1.5 倍程高い数值を見せ, また, 昭和 $58,59,60$ 年 の 3 年間における住宅火災での焼死老人発生経過状況を 見ると病気, 肢体不自由による焼死が $26 \%$ を占め, 火 
災時の自力脱出の困難性と対応の方法に問題があると報 告されている(佐藤, 1987) 文2)。さらに, 高齢化の進む 1990 年では, 年間 145 人前後の焼死者が出て, その内 $53 \%$ が 65 齢以上の高齢者であると大幅な増加となるこ とが推测されている(佐藤・小野田ほか, 1987)文引。こ うした中で高齡者が居住する住宅や戸建住宅，アパート および社会福祉施設や病院などの, 火災時における高秢 者一人ひとりの避難行動能力の特性や搬出能力等の両面 にわたって有効な体制作りを目指して研究を行ってい る。

本稿はその中で, 火災発生時に最も多数の死傷者を出 す危検性のある社会福祉施設において, 入所者の火災発 生時避難行動能力の測定と判断基準の一部試作, 職員お よび近隣居住者による避難・搬出体制, 防火管理・建 築・設備上に影在・潜在する危険要因等の実態調査を目 的とする。

\section{III. 調查研究の方法}

この調查研究は, 特別養護老人ホーム「X園」(表一 1$)$ を対象に, 次の要領で行った。

i）避難・搬出の可能度は, 入所者一人ひとりの心身状 況, 使用器具, 移動速度等のよって大きく変化すること から，ますこれらについての観察・測定を行い，その結 果と,『高㱓者の生活と健康に関する実態調查報告書 (財 団法人北海道高粭者問題研究協会一担当研究委員会委員 長浦沢喜一)』(竹川・杉山ほか，1986）文4)を参考に，避 難能力判定基準と判定表の作成を試みた。

\section{表一1 調查対象施設の概要}

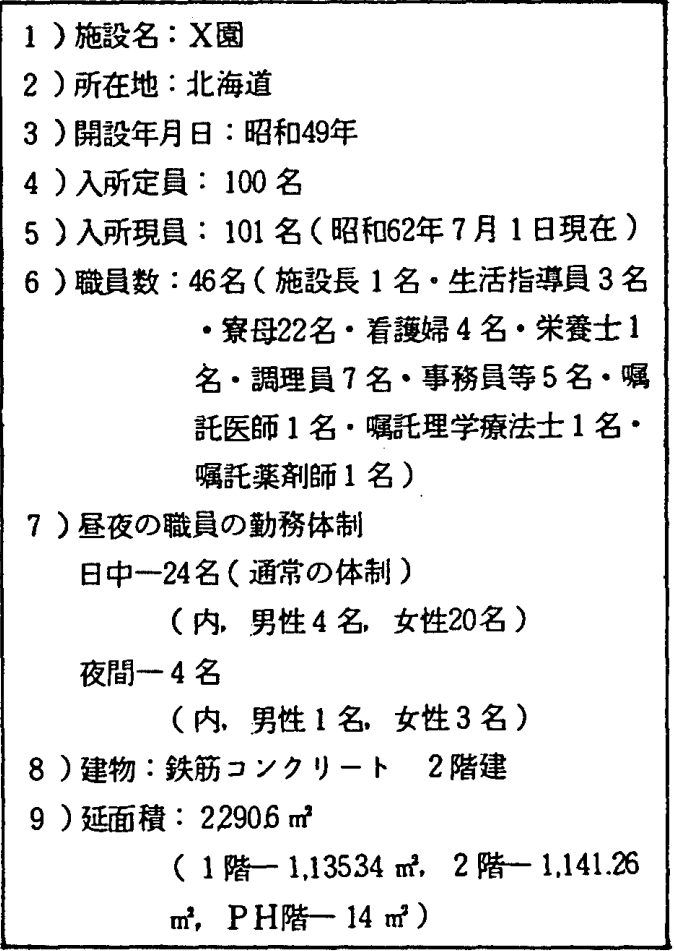

ii）次に，その判定基準によって評価された入所者が居 住する階別・居室別の分布状況を把握した上で、日中お よび夜間の消防訓練を実施し，一定時間内における避 難・搬出の可能性の度合いを調査した。

iii）またこれらと並行して，本施設の防火管理・建物・ 設備上に顕在・潜在する危険要因を調查した。

iv）最後に, これらの調查の結果判明した問題点を分析 し，対応策を検討した。

\section{V. 入所者の避離行動}

1）火災時避難行動能力評価基準の作成 火災時の行動は入院患者の行動能力に関する分析部2) (長澤・小滝ほか, 1984) 䴔でも報告されているように 日常行動とは基本的に異なる。そこで, 入所者各人の火 災時における避難行動能力を测定するため, A.DL（日 常生活動作能力）評価とは別に, 入所者の歩行状態, 速 度, 車椅子等の器具への移動, 階段の使用, スロープの 使用, 知的能力, 精神症状等を観察・想定しそれぞれ分 析した項目に点数を与え, それらの合計得点によって, 4 段階に避難能力を設定した。なお，それぞれの項目の 設定に当たり，下記事項について留意して作成した（韯 $-2)$ 。

(1) 歩行状態

入所者の日常の歩行状態を観察することによって分 類，7段階に区分けし得点化した。なお，寝たきりの判 定については, 前述の (竹川・杉山ほか, 1986)文6) が研 究・作成した知呆性老人判定表調査表』(表一3) 常生活動作能力》を参考に合計得点 19 点以上の者が綅 たきりとされているので本評価基準においても同様とし た。

(2) 速 度

本調査では, 自力で移動する者（独歩・杖使用・歩行 器使用・車椅子使用を問わず）全員の移動速度 $(\mathrm{m} /$ 秒) を計測したが, 一般的には速度計測は困難と思われるの で, それぞれの入所者の移動状態を観察し, 健常者の標 準的な歩行速度と比較できるよう分類，5段階に区分け し得点化した。

(3) 器具への移動

ベットなどから自力で歩行器や車椅子に移動できるか 否かについては，火災時における避難能力に大きく影響 するものと思われるので, 日頃, 入所者が個々に使用し ている器具への移動の能力について分類，4段階に区分 けし得点化した。

(4) 階段の使用

自力で階段を使用する能力について分類した。した がって, 歩行器・車椅子使用者および寝たきりの者は階 段を使用できないものとして分類，3段階に区分けし重 みをもたせ得点化した。 
表一2 火災時避難能力評価基準

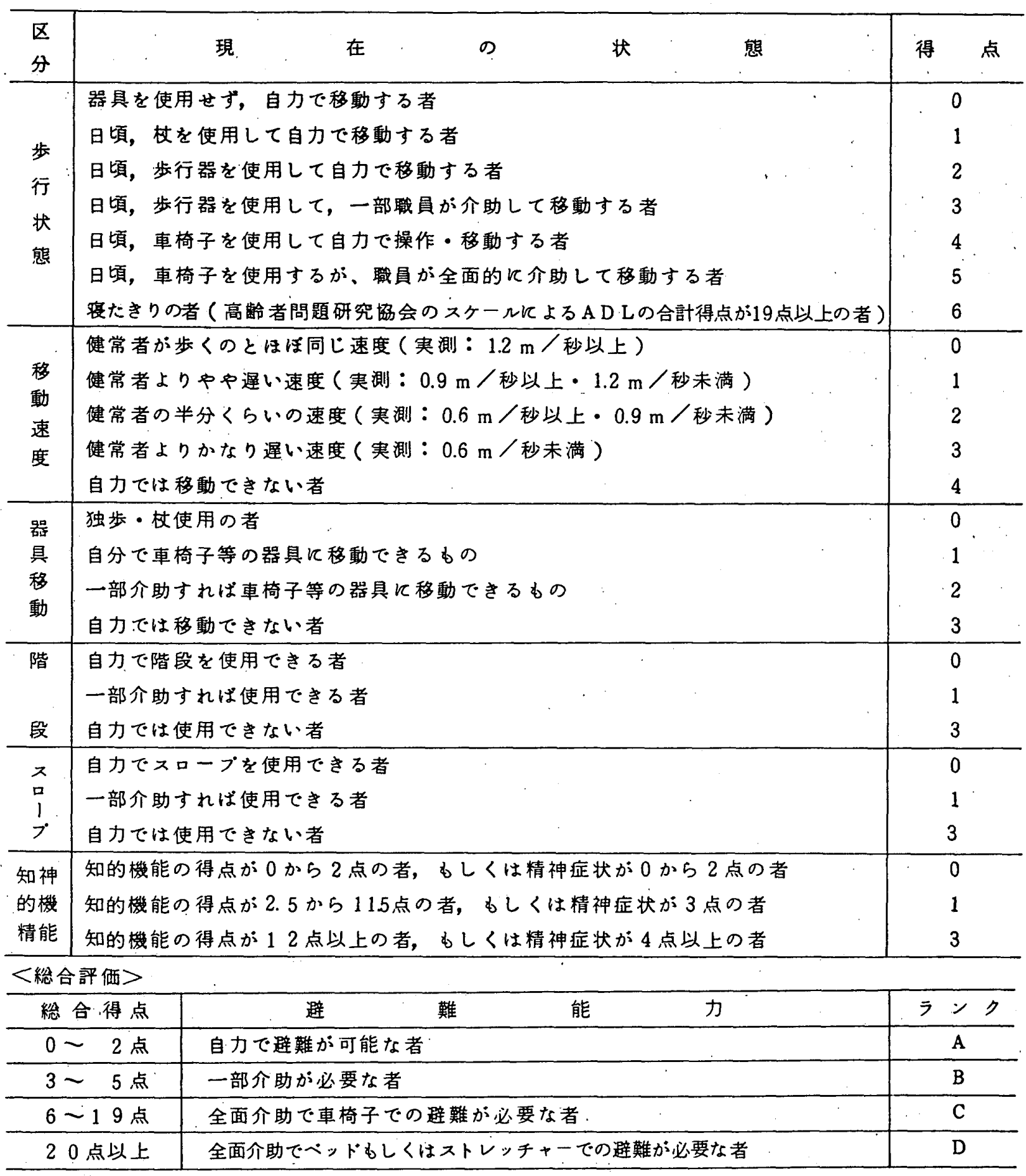

(5) スロープの使用

1 階と 2 階をつなぐスロープ（1/8 勾配）を自力で使 用する能力について分類した。むろん，車椅子を独力で 操作してスロープを降りることは不可能であるため, 車 椅子利用者および寝たきりの者はスロープは使用できな いものとしだ。なお，歩行器使用者の中で，スロープを 使用できる者は使用できるものとして分類；3段階に区 分けし重みをもたせ得点化した。

(6) 知的機能 - 精神症状

前揭の,「知呆性老人判定調査表」の<知的機能 $><$
問題行動および精神症状>を参考に分類，3 段階に区分 けし重みをもたせ得点化した。

(7) 総合評価

以上 6 項目について得点を集計し，その合計得点を もって火災時における避難能力を施設の職員が日常の処 遇の中で経験的に持つ評価をも含め総合的に，次のとお り分類した。
A：独力で避難が可能な者
B：一部介助が必要な者
$\mathrm{C}$ ：全面介助で，車椅子による避難が必要な者 
<知的㙨能>

\begin{tabular}{|c|c|c|c|c|}
\hline 項 & わ & かる る & わかる時とわからない時 & わからない \\
\hline お名前は何といいますか & & 0 & 2 & 4 \\
\hline 生年月日は（又は年齡は） & & 0 & 1.5 & 3 \\
\hline お生まれはどちらですか & & 0 & 2 & 4 \\
\hline 今の住所は（今は今どこにいますか） & & 0 & 1.5 & 3 \\
\hline 今日は何月何日ですか & & 0 & 1.5 & 3 \\
\hline （時計見せて）時刻は & & 0 & 1.5 & 3 \\
\hline 妹の娘を普通何と呼びますか & & 0 & 1.5 & 3 \\
\hline (「北海道」「男女」「赤」の字をみせて）何と読みますか & & 0 & 1.5 & 3 \\
\hline 18+19, 32-16はいくつですか & & 0 & 1 & 2 \\
\hline 数字 2・4・6を逆に言って下さい & & 0 & 1 & 2 \\
\hline
\end{tabular}

<問題行動及び精神症状〉

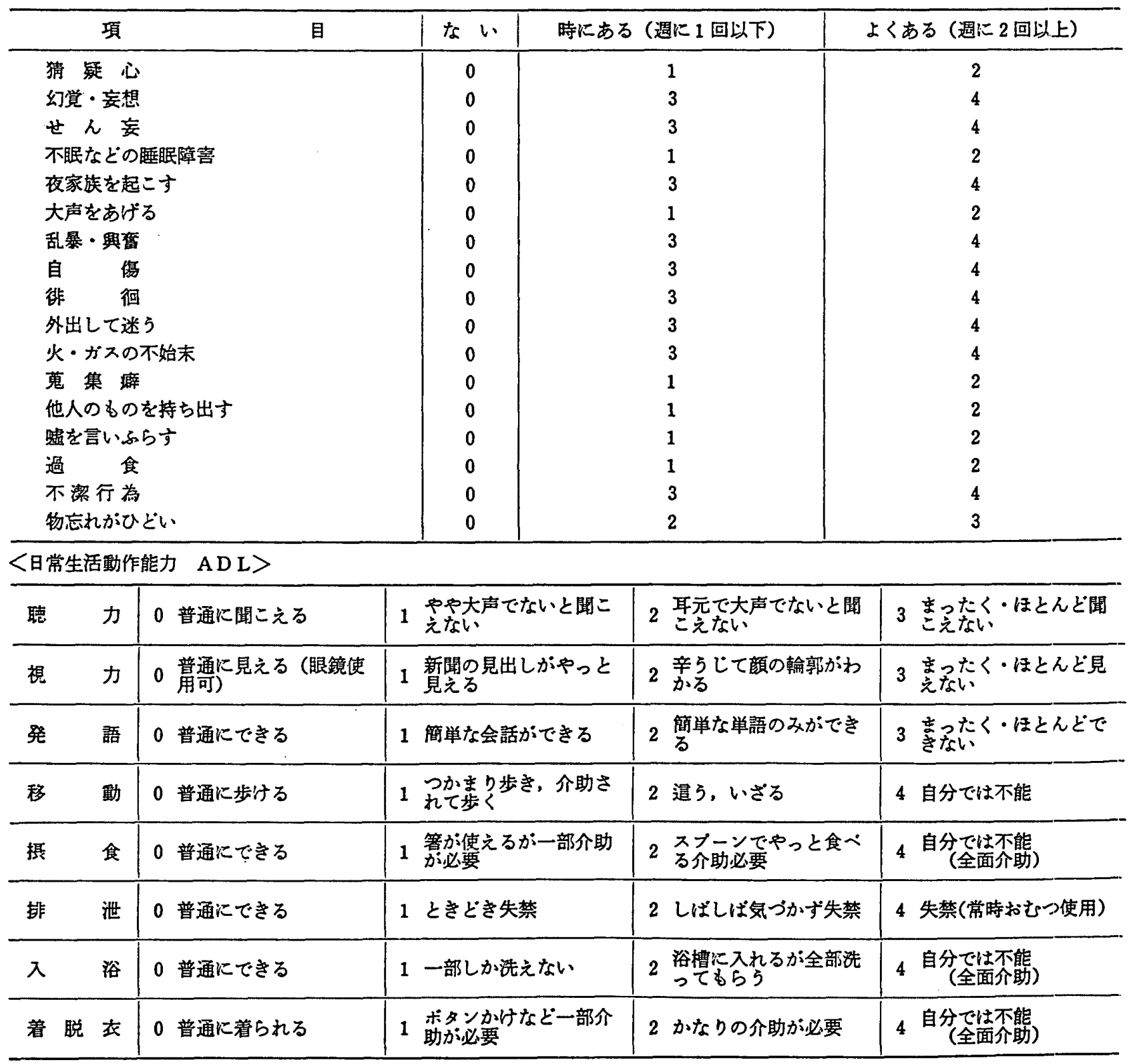

D : 全面介助で, ベットまたはストレッチャーによる避 難が必要な者

2）火災時避難能力評価基準による入所者の状況 前述の評価基準をもって本施設の入所者全員 (101 名)
を評価し（表一4）のような様式にその結果をまこめた。 これについて入所者全員の避難行動能力を, 運動能力と 知的・精神症状から見たのが（図一1）・である。

これらを評価ランク別に見ると, 自力で避難が可能な 
表一4 火災時における避難行動能力評価表（表一 2 による適用例）

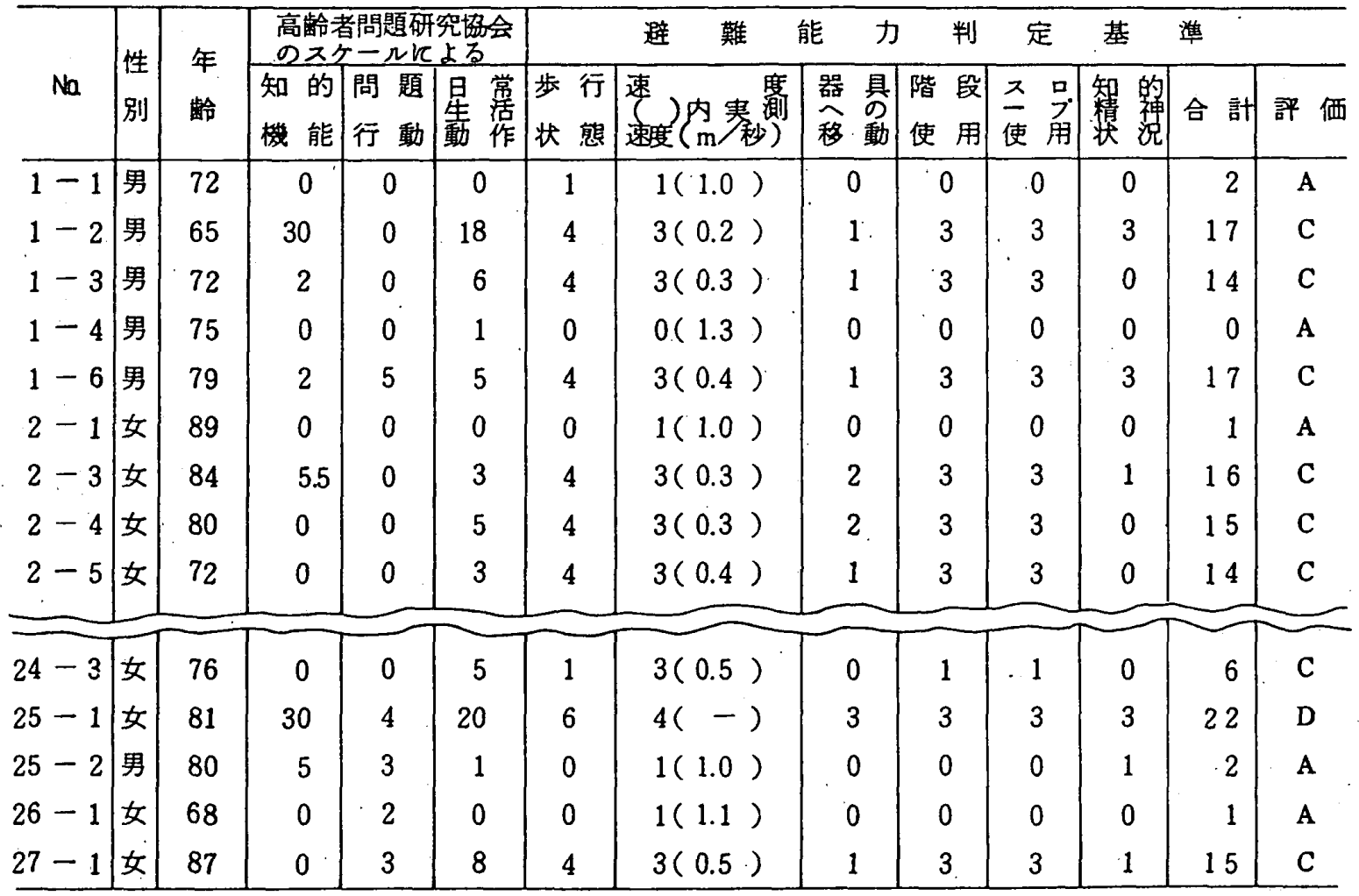

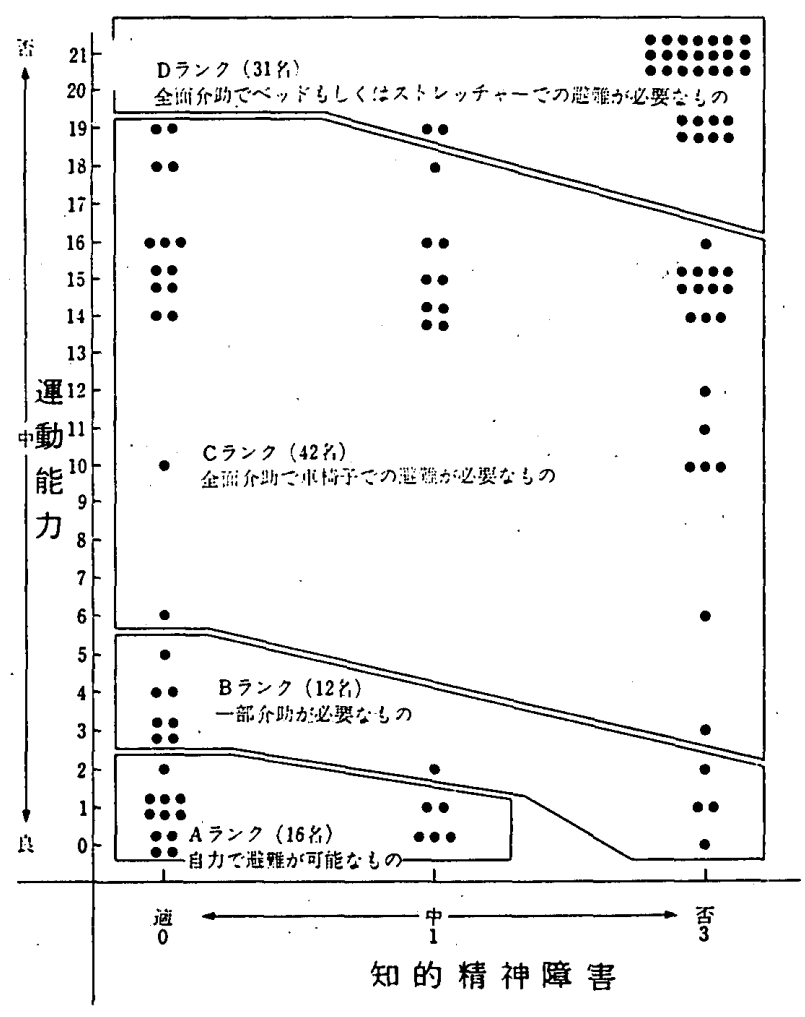

図一1 入所者全員の避難行動能力評価散布図

者 (A) は 16 名, 職員等による一部介助が必要な者 $(B)$ は 12 名,全面介助が必要で車椅子での避難をする者 (C) は 42 名と最も多く, 全面介助でキャス夕一付きベット もしくはストレッチャーで避難が必要な者（D）は 31 名となった（表一5）。
表一5 入所者の避難能力別居住階

\begin{tabular}{|c|c|c|c|c|c|c|c|c|c|}
\hline 避難能力 & \multicolumn{2}{|l|}{1} & \multirow{2}{*}{$\begin{array}{l}\text { 階 } \\
\text { 小計 }\end{array}$} & \multicolumn{2}{|c|}{2} & \multirow{2}{*}{$\begin{array}{l}\text { 階 } \\
\text { 小計 }\end{array}$} & \multirow{2}{*}{$\frac{\text { 合 }}{\text { 男 }}$} & \multicolumn{2}{|c|}{ 計 } \\
\hline 区 分 & 男 & 女 & & 男 & 女 & & & 女 & 計 \\
\hline A & 6 & 1 & 7 & 2 & 7 & 9 & 8 & 8 & 16 \\
\hline B & 6 & 1 & 7 & - & 5 & 5 & 6 & 6 & 12 \\
\hline $\mathrm{C}$ & 10 & 7 & 17 & 10 & 15 & 25 & 20 & 22 & 42 \\
\hline D & 2 & 10 & 12 & 9 & 10 & 19 & 11 & 20 & 31 \\
\hline 計 & 24 & 19 & 43 & 21 & 37 & 58 & 45 & 56 & 101 \\
\hline
\end{tabular}

社会福祉施設は自力避難困難者が多いとされている が, 本施設の場合, 自力避難困難者 $(\mathrm{B} \cdot \mathrm{C} \cdot \mathrm{D}$ の合計) は 85 名 $(84.2 \%)$ も占め, 火災が発生した際の避難・ 搬出が予想以上に難しいことを示している。

3）避難能力別の入所者居住位置

本施設における入所者の避難能力 $(\mathrm{A} \cdot \mathrm{B} \cdot \mathrm{C} \cdot \mathrm{D})$ 別の 居住状況は，(図一2）のとおりである。また，階別の居 住状況は（表一5）の之おりであるが，これによると， 自力避難可能者 (A) は 1 階に 7 名, 2 階に 9 名, 計 16 名おり,一部または全面介助が必要な自力避難困難者 (B.C.D) は 1 階に 36 名, 2 階に 49 名, 計 85 名が居 住している。

ここで注意しなければならないことは，避難・搬出に 最も人手を要する自力避難困難者が 2 階に 49 名もいる ということである。一般的には，自力避難困難者は極力 1 階または地上階に通ずる位置に居住させることが望ま しい。しかし現実には, 入所者同志の人間関係や心身状 

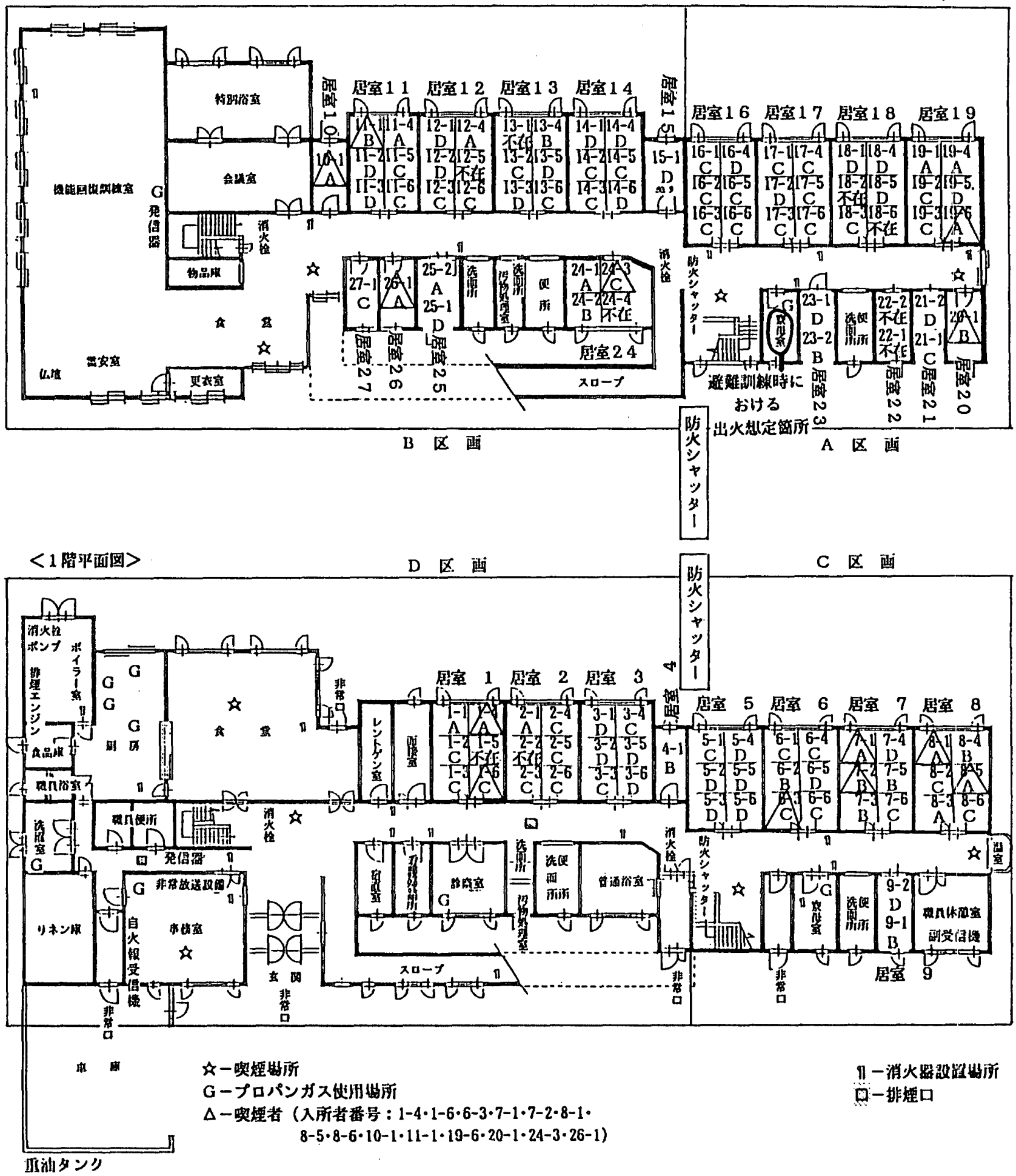
$\mathrm{A} ：$ 独力で避難が可能な者
B：一部介助が必要な者
C : 全面介助で, 車椅子による避難が必要な者
D：全面介助で，ベッドまたはストレッチャーによる避難が必要な者

図一2 避難能力別居住状況・火炎発生の潜在的危険箇所・消防用設備等 
況から来る処遇方法, 施設内部に配置されている諸設備 や構造等で居室割りされているのが実情である。

\section{V. 消防訓練の実施結果と問題点}

本施設の入所者の避難能力および居住状況には，前述 のように心理的にも物理的にも非常に難しい面がある が、これらの悪条件をいかに乗り越えて避難許容時間内 に避難・搬出できるかを調查するため，参加職員にはあ えてアドバイスをせずに，日中および夜間想定に消防訓 練を実施してもらった。

訓練は次の条件下において実施された。

(1) 訓練参加者

入所者：101名（男性 45 名, 女性 56 名)

職 員：日中訓練一21名（男性 5名，女性 16名） 夜間訓練一4 名（男性 1 名，女性 3 名）

(2) 職員 1 人当たり要救出者数

$$
\begin{aligned}
& \text { 日中訓練一 } 5 \text { 名 } \\
& \text { 夜間訓練- } 25 \text { 名 }
\end{aligned}
$$

(3) 潜在的出火の危険性をもつ䇢所

(図一2)のとおり

(4) 出火場所

2 階 A 区画寮母室（出火により最も被害が大きくなる 可能性の高い場所を選択した)。

(5) 避難・搬出許容時間

5 分, この時間の施定はフラッシュオーバーによる爆 発的火災拡大加他区画への延烧へと進む火災現象の進 行過程で避難搬出のための限界許容時間である。

ここでのフラッショオーバーの時間は（志田・辻本 · 柳澤，1986)刘による研究での標準設定値 180 秒 (3 分)

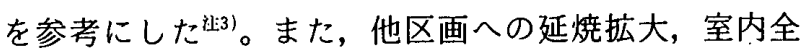
面火災へ至る総時間を 5 分として想定した。

(6) 消防用設備等の設置状況

本施設に設置されている消防用設備や避難用設備は次 のとおりであり，その設置場所は（図一2）のとおりで ある。

1 自動火災報知施備 (一式。調査開始後, 副受信機が 1 階職員休秝室一夜間勤務者の仮眠室一に設置され た)

\section{口. 漏電火災警報器 (一式)}

八 消火器 (小型 27 本, 大型 3 本)

二 屋内消火栓設備 (消火栓 4 力所)

木 非常放送設備'(一式)

へ 誘導灯 ( 16 力所)

卜防火シャッター (2力所)

于 排煙設備（排煙口 2 力所一 1 階のみ）

リスロープ (1 カ所・ $1 / 8$ 勾配・1階と 2 階をつなぐ 一幅 $2.4 \mathrm{~m})$

又 非常口' (正面玄関他 4 力所)
（1）日中訓練結果と問題点

1) ‘災の発見, 連絡 119 番通報, 非常放送, 消火器お よび屋内消火栓による消火，避難・搬出等は共にスム一 ズに進んだ。出火発見から出火元であるA区画の全員が 避難・搬出され，防火シャッターを完全に閉めるまでの 時間は, 5 分 58 秒, 同時に避難行動をとっていた B・ C.D 区画も含めた全入所者が避難・搬出完了するのに 要した時間は, 7 分 41 秒であった。

2） A区画の避難・搬出方法は，車椅子による者 9.名 (9台)，キャスター付きベット 2 人乗りによる者 12 名 (6 台), 歩行器使用による者 1 名 (要介助), 杖使用に よる者 1 名（自力），自力歩行による者 4 名であった。 それぞれの方法に要した介助職員数は, 車椅子 1 台に 1 人, キャスター付きベット 1 台に 2 人, 歩行器 1 台に 1 人で，A区画からスロープを通って正面玄関に搬出する 行動をそれぞれ 2 回程度, 繰り返して行っている。

3）出火元の A 区画の避難・搬出がこのように短時間で 終了したのは, 訓練参加職員 21 名中 $67 \%$ に当たる 14 名（男性 5 名，女性 9 名）がこの区画の入所者 27 名に 集中的に対応したためである。すなわち，このことは， 職員 1 名が入所者 2 名程度を搬出する体制でなければ, 自力避難困難者を火災から守れないことを示していると いえる。

4）問題は，火災が一挙に拡大するフラッシュ・オー バー後の避難・搬出許容時間 5 分（想定）を 58 秒超過 している点である。この想定時間内に危険区域からの搬 出を終了させ，さらに安全性を高めるため時間を短縮さ せるには，車椅子やキャスタ一付きベットを操作して 2 階の A 区画からスロープで 1 階正面玄関まで般出する垂 直移動ではなく，同じ 2 階のB区画（防火シャッターで 区切られる) のスロープロ付近に水平移動で一時避難さ せ，他の者に二次搬送させる方法が考えられる。この方 法の効果を確認するために, 北海道建設工学専門学校 IND 研究室の学生による実験を行ったところ, 介助者 1 人当たり車椅子の場合で $30 \sim 40$ 秒／回，キャスタ一 付きベットの場合には 40 60 秒/回の時間をセーブで きることが明確になった。火災は時間との戦いであり, 介助者 1 人の行動時間が 1 回につき 30 秒から 60 秒も短 縮できるということは, 水平移動による一時避難の有効 性を示し，また，火元からの一刻も早い脱出を必要とす るA区画にとっては極めて重要なことである。

\section{(2) 夜間訓練結果と問題点}

出火場所と参加入所者数は日中訓練と同一で, 夜間勤 務者は本施設の通常の夜間勤務体制と同様の 4 名（男性 1 名, 女性 3 名）とし，行動方法は指示せず夜間想定訓 練を実施した。その結果, 火元の発見, 通報, 非常放送 等に支障はなかったが，その後の行動に多くの間題がみ られた。その内の主なものとして, 次の項目が挙げられ 
る。

1) 勤務者が少ないため, 消火に重点を置いた行動を開 始し, 2 名 (男性 1 名, 女性 1 名) が 2 階 B 区画のスロー プ入口にある屋内消火栓操作を，他の 2 人（女性）は火 元 $\mathrm{A}$ 区画の各居室のドアを閉め火煙の侵入を防ぐととも に，搬出にあたった。

しかし, 屋内消火栓の操作方法に不慣れなため, 放水 が開始されたのは非常ベル鳴動の 1 分 29 秒後と大幅に 遅れている。

2）より大きな間題は, (図一2)のようにB区画のスロー プ入口にある屋内消火栓から $\mathrm{A}$ 区画へホースを引いたた め, スロープ入口前をホースが横切ることとなり, 避難 上大きな障害物を作ってしまったことである。このため, 車椅子による第一般送者（尞母）はホースを乗り越えよ うと試みた通過するのに時間がかかり, 次からはスロー プ使用をやめ $\mathrm{B}$ 区画の機能回復訓練室まで水平移動して いる。

この状態を見た他の寮母は，さらに消火の必要性を感 じたのか， B区画会議室前のもう一つの屋内消火栓から A区画へホースを引いたが，ホースの長さが足りず，使 用を中止し放置した。そのため, 今度は唯一の搬送通路 となる B区画の廊下にホースによる障害物ができてし まった。

このような複数のホース障害の発生により，日中訓練 でA区画全員の搬出が終了した 5 分 58 秒と同一時間内 にB区画に水平移動できたのは，A区画入所者 27 名中, 車椅子による 5 名および自力避難者の計 9 名のみであ る。

社会福祉施設の場合, 非常時には避難経路となる廊下 に車椅子や配奈車（給食用）等が置かれいることも見受 けられるが，通水によって小丸太のようになったホース の存在がより大きな般出障害となることが明らかとなっ た。

3）夜間訓練で確認されたもう一つの大きな問題は, 避 難・搬出に携わる人の絶対数の不足である。

本施設の消防計画では，夜間勤務者は男性 1 名（夜警 員), 女性 3 名（寮母）で構成されているが，消火・通 報活動のほかに 85 名の自力避難困難者を避難・搬出す ることは不可能であり，一刻も早く消防機関や近隣居住 者に連絡をとり, 救援を求めることが必要である。

そこで今後は, 各宿直者グループごとの夜間想定訓練 を繰り返して, どのような問題が発生するか実態を把握 し，それらに対応できる方法を見いださぬ限り，入所者 の安全は守れないといえる。

\section{V. 消防訓練結果からみた問題点への対策}

前述した間題点を解決するために，本施設では次のよ うな対策を講じた。

\section{1）応援体制の確立}

夜間火災時における避難・搬出のための人員を確保す るため，本施設では夜間勤務者以外の職員も含めた救援 体制がとられている。しかし，自宅から駆け付けるのに 6 分から 10 分かかる地域には 15 名の職員がいるが， 5 分以内に駆け付けることができる職員はわずか 1 名のみ であり，救援者のほとんじは避難・搬出許容時間内には 間に合わない。また，119 番通報してから消防隊が施設 に到着するのに要する時間は，本施設を管轄する消防㕷 で約 10 分間, 近くにある消防団でも約 7 分間とされ, 冬期や交通事情によってはもっと時間がかかるおうれも あることから， 5 分以内の消火・救出は望めない。

そこで, 5 分以内の消火,できればフラッシュォーバ-の 3 分以内に駆け付けて来れる近隣の住民や施設の協力 が必要となる。

本施設ではこの調査期間中に, 隣接する老人渟門病院 および身体障害者授産施設と, 夜間火災時の三者相互協 力の楴結を, 消防署の指導のもとに行い, 3 分程度で 9 名の救援者が得られる体制を確立した。

さらに，火災時における社会福祉施設等の避難体制の 弱さを知った地域住民は，自分たちも応援体制を構築す る必要性を感し，自主的に関係当局へ行政的手段を講じ るよう要望を出している。この住民による応援件制が整 備されると，5分以内に駆け付けることができる救援者 がさらに 10 名近く增え, 本施設の日中の職員体制と同 程度となることから，搬出能力は大幅に向上する。

しかし，この近隣居住者による救援にも間題以残って いる。それは近隣居住者といえぞも, 本施設の建物の棈 造や入所者の特性などを熟知していない点である。

この件に関しては，本施設が近隣居住者に対し，消防 訓練や内部的な説明会等に参加してもらうよう積極的に 働きかけ, 建物内部, 入所者の特性や避難能力を認識し てもらい，車椅子やキャスター付きベットの操作方法等 をマスターしておいてもらう努力が必要である。いずれ にしても, この外部からの応援者が実際に避難・搬出に 当たっていけるようにするためには，慎重な事前準備之 訓練を要するといえる。

2）屋内消火栓ホース障害の解消

本施設の消防用設備に関する久点は, 前述の上うに屋 内消火栓ホースが 2 階からの唯一の避難・搬出用のス ロープ入ロに障害を設けてしまうことである。この問題 の解決なしには, 本施設の 2 階から 1 階への避難・搬出 体制の確立は不可能と言える。

そこで,この問題を解決するには，スプリングラー設 備を設置するか, 屋内消火栓を移設することが影良の方 法と言える。

3）二方向へ避難口の確保

本施設の建築構造上の最も大きな欠点は，2 階のA区 
画と，1·階のC区画に二方向避難対策が講じられていな いことである。

今回の訓練における火災出火場所を 2 階 $\mathrm{A}$ 区画の寮母 室に設定したのも，この区画には右側への避難口および 避難階段またはスロープ等がなく, 出火時には最も危険 なエリアとなるためである。

4)・キャスター付きベットの活用

現在, 防災弱者が使用できる避難器具等はほとんどな く,これらの人々の生命を火煙から守るためには, 出火 元の区画から他の安全な区画へ素早く水平移動する一次 避難がポイントとなるだろう。

その方法としては，車椅子・キャスタ一付きベットに よる移送, 担送, 背負い, シーツや布団の活用等がある が，居室内に常備されており，複数の防災弱者を一挙に 移動させることのできるものとしては，キャスタ一付き ベットが本施設では最も効率的であった。

次に示す項目は，キャスター付きベットを使用する場 合の留意点である。

(1) 各居室の入所者の避難能力を事前評価し, 非常時に は，どの人々をどのキャスター付きベットに移動して搬 出するかの組み合わせを明確にしておかねば，非常時に 迅速な対応はできない。

(2) キャスター付きベットの操作には, 方向性の安定と 安全確保のため; ベットの前後に 1 人ずつ操作する者が 配置される必要がある。この 2 人の行動効率を高めるた めには，1 ベットに 3 人を同乗させることが有効である。 今回の実験で，少々きついが実行可能なことが確認され ている。

(3).介助者が 2 人ペアということは，他のベットの入所 者を搬送するベットへ移動させる際のスピードアップ と, キャスターのストッパー開放，室内での搬出通路ゔ くり，ドアの開放等，雑務処理のためにも有効である。 (4) キャスタ一付きベットによる搬送の効率をさらに向 上させるには，ベット間移動を専門とするぺアを作るこ とが考えられる。このペアは各室を回って 3 人乗りベッ 卜を次々とつくり，他の移動専門のペアがいつでも搬出 できる状態にしながら，在室者の不安解消や消火防煙対 策を講じる役目を果たすこともできる。

(5) 非常時には，総括的に状況を把握して指示する者が いないと，重複した行動や在室者の見落とし，無䭾な行 動が発生するので，このベット間移動のペアにその役割 を持たせることも検討に值するだろう。

\section{VI. まとめ}

これまで見てきたように，本施設の実態には設備，構 造のハード面，避難方法などのソフト面において，いく つかの間題点がある。ここでは今後さらに取り組まなけ ればならない課題を整理してまとめとした。
（1）施設・設備面の改善

1）避難用バルコニー・ベランダの設置

二方向避難を可能にするため，2 階居室等から直接外 部に避難できる「避難用バルコニー」の設置と，同様に 1 階部分についても『避難用ベランダ』を設置する。

2）非常口の改修および増設

同時に，現在は居室等の通常の空であるものを，避難 用バルコニーやベランダへの出口として使用できるもの. に改修するとともに，一部，非常口の増設を図る。

3） スプリンクラー設備の設置

初期消火に効果的であるスプリンクラーの設置は不可 欠である。特に厚生省レベルでは全国の社会福祉施設で 設置するよう指導しており，補助金の交付も制度化され ていることから，早急な設置を望みたい。(本施設は， 平成元年度設置完了)

4) 安全区画の確保

自力避難困難者を少数の宿直者で守るには，水平一時 避難が有効である。このため, 各階に防火戸又は防火 シャッッーを設置し，安全区画を確保する。

5）非常通報装置の設置

実火災時には 119 番通報を忘れたり，遅れがちになる。 特に, 夜間火災時には外部職員や近隣居住者へ連絡して 応援を求めねば二次避難・搬出ができない状沿下にあ る。これらに対応するため, 一つの押しボタンを押すこ とによって，または自動的に，消防機関や重要連絡先へ 通報できる非常通報装置の設置が必要である。

6) 排煙口の増設

火災時の死傷者は, 災や熱より煙によって多く発生し ている。そこで現在 1 階の 2 力所にしか設置されていな い排煙口を増設し，煙による危険性を軽減化させること が大切である。

\section{（2）避難体制の整備}

1) 入所者の避難行動能力の熟知

今回試作した避難行動能力評価基準 ${ }^{(4)}$ )等をもつて全 職員が入所者の避難行動能力を熟知し, 火災時での十分 な安全性を考慮した居室割りをすることが重要である。

2）消防訓練の充実

いくつかの火災発生のケースを想定して, その出火場 所や火災規模などに応じた消火・通報・避難・搬出体制 の研究と, 実効性ある訓練を総合的に行うことが望まれ る。特に消防署との深い連携は重視されるべきで, 本施 設の場合, 消防署のキメ細かい指導と応援もあることか ら，より充実した体制の整備を期待したい。また，実際 の消防訓練と併せて, 職員会議などにおいて机上で出火 場所を想定し，それぞれの職員がどのような救援をし， どのような消火活動に当たるかなど，〈机上模擬訓練〉 を日常的に実施することも有効である。 


\section{䜣.おわりに}

私どもは，概念的には社会福祉施設の火災時における 脆弱性を認識しながらも，陽気寮火災や松寿園火災が発 生するまで，その具体的対応策検討への努力は十分とは 言いがたい面があった。

しかし現実には，高㱓化社会のさ中にあり，高秢者が 居住する建物が増え，火災時における自力避難困難な高 路者も増え続けている。

尊い生命を火災から守るためには, 高路者が居住する 建物一つ一つの火災に対する危険度または安全度を確認 し，それぞれに適合した対策を講じた事前の体制整備が 必要なのである。

今回の調査研究は，その一環としてのものであるが, 今後もこの調査研究をベースに, より実践的な避難・行 動能力評価基準の作成, 特に施設職員が経験的に判断す る避難行動能力への適合性を検討するとともに, ソフト 面・ハード面を考慮した防火・避難等の体制の策定に向 かって, 研究を進めていきたい。

最後にこの調查研究に全面的な協力をしていただいた 特別養護老人ホーム聖芳園石川秀也課長, 防災指導セン タ一小野田 弘主幹, 避難訓練調査では特別養護老人 ホーム聖芳園の樋口達夫園長, 北海道建設工学導門学校 IND 研究室の学生の皆样, また防災関係での貴重な資 料を提供していただいた日本大学理工学部志田弘二助 手, 火災時避難能力評価基準作成に際し，ご指導いただ きました札幌医科大学杉山善朗教授ならびに論文作成に 際しご指導いただきました日本大学理工学部木下茂徳教 授に心から感謝の意を表します。

\section{注}

1）高龄者が居住する戸建住宅・共同住宅・福祉施設・医療 施設での建物における危険要因と問題点の把握を目的に 調査・研究が行われ, その結果予想以上に高跉者を取り 巻く危険要因が多いことと死傷率が高いことが確認され, その問題点は非常災害・日常災害ともその被災損傷の原 因はソフト面にあり，対応策として「防災訓練・教育シ ステムの開発と施設つくり」の提案がされている。
2）この研究は入院患者の行動能力を非常時の移動能力と日 常生活での行動能力とにわけて, 各々の実態を把握する とともに, 行動能力を判断する要因の解明を目的として いる。

3）この研究では, 火災状況・煙流動シミュレーションから フラッシュオーバーの発生を火災室のドアの開閉状況で 180 秒 (開いている)，273秒（閉じている）と設定して いる。このため本研究対象特別養護老人ホームX園でゆ 各部屋の状況を検討すると，ドアは開かれて㧍り，180 秒とした。この傾向は特養ホームでの一般的な状況でも ある。

4) 今回の研究で作成した火災時避難行動能力評価基準を もって，他の施設 3 力所（入園者合計 285 名）に対して 実態調查を行ったところ，評価基準による総合評価とそ れぞれの施設職員が経験的に判断する避難行動能力と約 $2 \%$ 程度の極めて低率ではあるが，適合しない事例があ り，現在この点に検討を加え，より適合率を有するもの へと改良をしている。

\section{参考文献}

1）小野田 弘，佐藤克之：高齡化社会における住環境の研 究, 高龄者問題研究, No. 2, 北海道高路者問題研究協会, pp. $59 \sim 74,1986.3$

2）佐藤克之：火災に対する老人の居住空間についての研究， 北海道における住宅火災での焼死老人とその棈造, 日本 建築学会学術講演梗概集, 1987

3）佐藤克之・小野田 弘ほか：火災に対する老人居住空間 についての研究, 高齢者問題研究, No.2, 北游道高路者 問題研究協会, pp. 237 - 260, 1986.3

4）竹川忠男・杉山善朗ほか：高制者の生活と健䐂に関する 実態調查報告書, 北海道高齢者問題研究協会, 一次調查 報告書, pp. $210 \sim 211$ ，二次調查報告書, pp. 89 102, 1986

5）長澤 泰・小滝一正ほか：入院患者の行動能力の関する 分析, 病棟の建築計画の基礎的研究，日本建筑学会論文 報告集，第 346 号, pp. 164 173，1984. 12

6）竹川忠男 - 杉山善朗任 : 前揭書 4)

7）志田弘二・辻本 誠・柳澤 忠:火災発生に伴う人命危 険の評価法, 日本建築学会計画系論文報告集, 第 368 埮, pp. $69 \sim 78,1986.10$

（1989 年 11 月 2 日原稿受理，1990 年 5 月 21 日採用决定） 